\title{
PENGEMBANGAN PROFESIONALISME PENDIDIK DALAM UPAYA PENINGKATAN MUTU PENDIDIKAN
}

Muhammad Syukur

UIN Syarif Hidayatullah Jakarta DPK Institut Sains dan Teknologi AI-Kamal msyukur0201@gmail.com

\section{ABSTRAK}

Pendidik merupakan unsur pendidikan yang paling berpengaruh dalam peningkatan kualitas pendidikan. Dalam sejarah peradaban dunia, pendidik berada di garda terdepan dalam menciptakan kualitas sumber daya manusia. Pendidik merupakan profesi yang hanya dapat dilaksanakan secara efektif dan efisien oleh seseorang yang dipersiapkan untuk menguasai kompetensi tertentu melalui pendidikan atau pelatihan khusus, terutama pendidikan profesi. Dalam rangka mencapai mutu yang tinggi dalam bidang pendidikan, peranan pendidik sangatlah penting, bahkan sangat utama. Untuk itu, profesionalisme pendidik harus ditegakkan dengan cara pemenuhan syaratsyarat kompetensi yang harus dikuasai oleh setiap pendidik, baik di bidang penguasaan keahlian materi keilmuan maupun metodologi. Untuk mencapai kondisi pendidik yang profesional, para pendidik harus menjadikan orientasi mutu dan profesionalisme pendidik sebagai etos kerja mereka dan menjadikannya sebagai landasan orientasi berperilaku dalam tugas-tugas profesinya. Begitu pula, seorang yang ingin menjadi pendidik yang profesional perlu senantiasa beradaptasi dan merespon tantangan paradigma baru profesi pendidik. Seorang pendidik hendaknya memiliki motivasi kuat untuk menjadi maju dan profesional. Semua pendidik bisa menjadi profesional asalkan ada niat, keinginan, motivasi, dan komitmen dalam melakukan dan menggapainya.

Kata Kunci: pendidik, profesionalisme, mutu

\section{PENDAHULUAN}

Masa depan suatu bangsa sangat erat kaitannya dengan komitmen politik dan upaya nyata bangsa itu dalam membangun mutu pendidikan untuk mencerdaskan generasi mudanya. Sedangkan keberhasilan suatu bangsa dalam membangun mutu penddidikan sangat ditentukan oleh mutu pendidiknya. Setidaknya hal itu dapat dicermati di negara-negara maju atau yang sedang bergerak maju.

Salah satu cita-cita kemerdekaan nasional Indonesia adalah keinginan untuk mencerdaskan kehidupan bangsa sebagaimana yang tertuang dalam Pembukaan UUD 1945. Semangat tersebut seharusnya memberikan spirit dan komitmen semua elemen bangsa, khususnya para penyelenggara 
negara untuk menyatukan visi dan tekad dalam membangun mutu pendidikan nasional.

Menurut Soedijarto (Soedijarto, 2003: 108), cita-cita mencerdaskan kehidupan bangsa melalui penyelenggaraan satu sistem pengajaran nasional tidak lain dimaksudkan untuk membangun negara berperadaban bangsa Indonesia yang berkarakter. Pancasila dan UUD 1945 mengandung nilai-nilai dasar dari negara peradaban bangsa Indonesia yang merdeka.

Rendahnya mutu pendidikan telah memberikan akibat langsung pada rendahnya mutu dan lemahnya karakter sumber daya manusia bangsa kita. Karena proses untuk melahirkan sumber daya manusia yang bermutu dan berkarakter hanya bisa dilakukan melalui jalur pendidikan danproses pembelajaran yang bermutu pula. Human Development Index (HDI) yang dikeluarkan oleh UNDP melaporkan bahwa Indonesia berada pada ranking 108 pada tahun 1998, 109 pada tahun 1999, dan ranking 111 pada tahun 2004 dari 174 negara yang diteliti. (E.Mulyasa, 2007: 3).

Bila ditilik lebih jauh rendahnya mutu pendidikan bangsa itu tidak lepas dari kondisi tenaga pendidik sebagai salah satu unsur penyelenggara pendidikan. Tenaga pendidik mempunyai posisi dan peranan yang sangat penting dan strategis dalam keseluruhan upaya pencapaian mutu pendidikan. Mutu pendidikan dapat dicapai apabila tenaga pendidik hidup dengan memadai, memiliki penghasilan yang mencukupi sehingga mereka mampu memberikan perhatian secara memadai dalam menunaikan tugasnya.

Terlebih lagi, dunia pendidikan sedang diguncang oleh berbagai perubahan sesuai dengan tuntutan dan kebutuhan masyarakat serta ditantang untuk dapat menjawab berbagai permasalahan lokal dan perubahan global yang terjadi begitu pesat. Globalisasi telah mengubah cara hidup manusia sebagai individu, warga masyarakat, dan warga bangsa. Tidak seorang pun dapat menghindar dari arus globalisasi. Setiap individu dihadapkan pada dua pilihan. Pertama, dia menempatkan dirinya dan berperan sebagai pemain dalam arus globalisasi; dan kedua, dia menjadi korban globalisasi. Arus globalisasi juga masuk dalam wilayah pendidikan dengan berbagai implikasi dan dampaknya, positif dan negatif. Dalam konteks ini tugas dan peranan seorang pendidik sebagai ujung tombak dunia 
pendidikan sangat strategi dalam menciptakan sumber daya manusia yang dapat berkompetisi dengan generasi bangsa lain dalam suatu masyarakat dunia.

Sejalan dengan perkembangan sains dan teknologi dan meluasnya pengaruh globalisasi, pendidik senantiasa dituntut dapat mengimbangi perkembangan sains dan teknologi yang terus berkembang. Seorang pendidik diharapkan mampu pula menghasilkan peserta didik sebagai sumber daya manusia yang memiliki kompetensi tinggi dan siap menghadapi tantangan hidup dengan penuh percaya diri.

Pendidik merupakan seorang yang paling bertanggung jawab dalam peningkatan kualitas pendidikan. Dalam sejarah peradaban dunia, pendidik berada di garda terdepan dalam menciptakan kualitas sumber daya manusia. Pendidik berhadapan langsung dengan peserta didik di ruang kelas melalui proses pembelajaran. Di tangan pendidik akan dihasilkan peserta didik yang berkualitas, baik secara akademis, skill, kematangan emosional, moral, dan mental spiritual. Dari peran dan fungsi pendidik akan dihasilkan generasi muda yang siap hidup dan berkompetisi dengan tantangan zaman yang berbeda. Karena itu, diperlukan sosok pendidik yang mempunyai kualifikasi, kompetensi, dan dedikasi tinggi dalam menjalankan profesinya.

Atas dasar pertimbangan di atas, tulisan ini akan mencoba menganalisis secara singkat: (1) Hakikat Profesionalisme Pendidik; (2) Hakikat Mutu Pendidikan; (3) Tantangan Profesi Pendidik pada Era Globalisasi; dan (4) Strategi Meningkatkan Profesionalisme Pendidik.

\section{PEMBAHASAN}

\section{Hakikat Profesionalisme Pendidik}

Istilah profesi sering diberi makna secara kabur, karena memang ada perbedaan antara sisi pandang akademik dengan sisi pandang praktikal. Kekaburan makna profesi dapat diperjelas dengan mendudukkannya, baik secara etimologi maupun terminologi. Secara etimologi profesi berasal dari bahasa Inggris profession atau bahasa Latin profecius yang artinya mengakui, pengakuan, menyatakan mampu, atau ahli dalam melaksanakan pekerjaan tertentu. 
Penyandang profesi boleh mengatakan bahwa dia mampu atau ahli dalam melaksanakan pekerjaan tertentu asalkan pengakuannya itu disertai oleh bukti riil bahwa dia benar-benar mampu melaksanakan suatu pekerjaan yang diklaim sebagai keahliannya. Akan tetapi pengakuan itu idealnya berasal dari masyarakat atau pengguna jasa penyandang profesi itu. Di mana pengakuan itu berangkat dari karya ilmiah atau produk kerja lain yang dihasilkan oleh penyandang profesi itu. Pengakuan itu terutama didasarkan atas kemampuan konseptual aplikatif dari penyandang profesi itu. Bagi pendidik, pengakuan itu dapat berasal dari warga belajar, kolega, kepala satuan pendidikan, pengawas, masyarakat umum, termasuk negara.

Secara terminologi profesi dapat diartikan sebagai suatupekerjaan yang mempersyaratkan pendidikan tinggi bagi pelakunya dengan titik tekan pada pekerjaan mental, bukan pekerjaan manual. Kemampuan mental yang dimaksud di sini adalah ada persyaratan pengetahuan teoritis sebagai instrumen untuk melakukan perbuatan praktis.

Merujuk pada definisi di atas, pekerjaan yang menuntut keterampilan manual atau fisikal, meski level tinggi, tidak digolongkan ke dalam profesi. Sehingga tidak muncul organisasi profesi seperti Ikatan Tukang Semen Indonesia, Ikatan Tukang Jahit Indonesia, dan sebagainya. Bandingkan dengan Ikatan Dokter Indonesia, Asosiasi Dosen Indonesia, dan Persatuan Guru Republik Indonesia, dan Ikatan Sarjana Pendidikan Indonesia. Kalau pun ada ikatan-katan atau organisasi semacam itu, tidak dapat diberi makna sebagai organiasi profesi yang dipakai dalam bahasa akademik.

Ada tiga pilar pokok yang ditunjukkan untuk suatu profesi, yaitu pengetahuan, keahlian, dan persiapan akademik. Pengetahuan adalah segala fenomena yang diketahui yang disistematisasi sedemikian rupa sehingga memiliki daya prediksi, daya kontrol, dan daya aplikasi tertentu. Pada tingkat yang lebih tinggi, pengetahuan bermakna kapasitas kognitif yang dimiliki oleh seseorang melalui proses belajar. Keahlian bermakna penguasaan substansi keilmuan di mana hal itu dapat dijadikan acuan dalam bertindak.

Pendidik harus memiliki keahlian di bidangnya, disertai keterampilan mentransformasikannya kepada warga belajar. Keahlian juga bermakna kepakaran dalam cabang ilmu tertentu untuk dibedakan dengan kepakaran 
lainnya. Persiapan akademik mengandung makna bahwa untuk mencapai derajat profesional atau untuk memasuki jenis profesi tertentu diperlukan persyaratan pendidikan khusus. (Sudarwan Danim dan Wiwien W. Rahayu, 2009: 34-35).

Selain istilah profesi, kita pun mengenal istilah profesional dan profesionalisme. Kata profesional merujuk kepada dua hal. Pertama, orang yang menyandang suatu profesi, seperti "Toni seorang profesional". Orang yang profesional biasanya melakukan pekerjaan secara otonom dan dia mengabdikan diri pada pengguna jasa disertai dengan rasa tanggung jawab atas kemampuan profesionalnya itu. Istilah otonom di sini bukan berarti menafikan kolegialitas (kerja sama), melainkan harus diberi makna bahwa pekerjaan yang dilakukan oleh seorang profesional itu benar-benar sesuai dengan keahliannya.

Sedangkan istilah profesionalisme berasal dari bahasa Inggris professionalism yang secara leksikal berarti sifat profesional. Orang profesional memiliki sifat dan sikap yang berbeda dengan orang yang tidak profesional, meski mereka melakukanpekerjaan yang sama atau katakanlah berada pada satu ruang kerja. Tidak jarang pula orang yang berlatar belakang pendidikan yang sama dan bekerja pada tempat yang sama menampilkan kinerja profesional yang berbeda serta berbeda pula pengakuan masyarakat terhadap mereka. Profesionalisme dapat diartikan sebagai komitmen para anggota suatu profesi untuk meningkatkan kemampuan profesionalnya dan terus-menerus mengembangkan strategi yang digunakannya dalam melakukan pekerjaan sesuai dengan profesinya. Siapa saja yang menyandang profesi sebagai pendidik, dia harus secara kontinyu menjalankan tugas profesinya dan mengembangkan kompetensi pekerjaannya.

Hasil studi beberapa ahli mengenai sifat-sifat profesi itu menghasilkan kesimpulan sebagai berikut; 1) Kemampuan intelektual yang diperoleh melalui pendidikan, 2) Memiliki pengetahuan spesialisasi, 3) Memiliki pengetahuan praktis yang dapat digunakan langsung oleh orang lain atau klien, 4) Memiliki teknik kerja yang dapat dikomunikasikan, 5) Memiliki kapasitas mengorganisasikan kerja secara mandiri, 6) Mementingkan kepentingan orang lain, 7) Memiliki kode etik, 8) Memiliki sanksi dan 
tanggung jawab komunitas, 9) Mempunyai sistem upah; dan, 10) Memiliki budaya profesional.

Sedangkan yang dimaksud tenaga pendidik menurut Undang-Undang No. 20 Tahun 2003 tentang Sistem Pendidikan Nasional Pasal 1 adalah seseorang yang berkualifikasi sebagai guru, dosen, konselor, pamong belajar, widyaiswara, tutor, instruktor, fasilitator, dan sebutan lain yang sesuai dengan kekhususannya serta berpartisipasi dalam menyelenggarakan pendidikan. Pendidik sebagai tenaga profesional bertujuan untuk melaksanakan sistem pendidikan nasional dan mewujudkan tujuan pendidikan nasional, yaitu berkembangnya potensi peserta didik agar menjadi manusia yang beriman dan bertaqwa kepada Tuhan Yang Maha Esa, berakhlak mulia, sehat, berilmu, cakap, kreatif, mandiri, serta menjadi warga negara yang demokratis dan bertanggung jawab. (Undang-Undang No. 20 Tahun 2003 tentang Sistem Pendidikan Nasional Pasal 3).

Profesi pendidik merupakan bidang pekerjaan khusus yang dilaksanakan berdasarkan prinsip-prinsip antara lain; 1) Memiliki bakat, minat, panggilan jiwa, dan idealisme, 2) Memiliki komitmen untuk meningkatkan mutu pendidikan, keimanan, ketaqwaan, dan akhlak mulia, 3) Memiliki kualifkasi akademik dan latar belakang pendidikan sesuai dengan bidang tugas, 4) Memiliki tanggung jawab atas pelaksanaan tugas keprofesionalan, 5) Memperoleh penghasilan yang ditentukan sesuai dengan prestasi kerja, 6) Memiliki kesempatan untuk mengembangkan keprofesionalan secara berkelanjutan dengan belajar sepanjang hayat, 7) Memiliki jaminan perlindungan hukum dalam melaksanakan tugas profesional; dan 8) Memiliki organisasi profesi yang mempunyai kewenangan mengatur hal-hal yang berkaitan dengan fungsi keprofesionalan.

Dengan demikian jelas bahwa pendidik merupakan profesi yang hanya dapat dilaksanakan secara efektif dan efisien oleh seseorang yang dipersiapkan untuk menguasai kompetensi tertentu melalui pendidikan atau pelatihan khusus, terutama pendidikan profesi. Oleh karena itu, pendidik harus memenuhi persyaratan atau kualifikasi atau kompetensi sesuai dengan jenis dan jenjang satuan pendidikan tempatnya bekerja. Untuk itu jabatan pendidik sebagai profesi seharusnya mendapat perlindungan hukum untuk menjamin agar pelaksanaannya tidak merugikan berbagai pihak yang 
membutuhkan jasanya secara profesional dengan memberikan penghargaan finansial dan nonfinansial yang layak bagi sebuah profesi.

Hal ini sejalan dengan pendapat Eric Hoyle (1981: 9),bahwa the strength of an education system must largely depend upon the quality of its teacher's. Demikian pula Oteng Sutisna (1991: 109) mengemukakan bahwa mutu program pendidikan tidak saja bergantung kepada konsep-konsep program yang cerdas, tetapi juga kepada personil pendidik yang mempunya kemampuan dan keinginan untuk berprestasi.

\section{Hakikat Mutu Pendidikan}

Menurut Deming (W. Edward Deming, 1986:23), mutu adalah kesesuaian dengan kebutuhan pasar. Sedangkan menurut Juran (1989:21)mutu suatu produk adalah kecocokan penggunaan produk (fitness for use) untuk memenuhi kepuasan pelanggan. Sejalan dengan dua pendapat tersebut, Feigenbaum (1988:30) mengatakan bahwa mutu adalah kepuasan pelanggan sepenuhnya (full customer satisfaction).Sedangkan menurut Crosby (Philip B. Crosby, 1987: 34), mutu adalah conformance to requirement, yaitu sesuai dengan yang disyaratkan atau distandarkan.

Pendapat para pakar di atas memberikan gambaran yang jelas bahwa konsep mutu bersifat dinamis. Jadi, mutu merupakan kondisi dinamis yang berhubungan dengan produk manusia/tenaga kerja, proses, dan tugas serta lingkungan yang memenuhi atau melebihi harapan pelanggan.

Konsep mutu dalam bidang pendidikan berbeda dengan industri. Perbedaannya terletak pada unsur manusiawi yang diproses sebagai hasil. Oleh karena itu, akhir penilaian mutu yaitu pada mutu lulusan. Mutu lulusan sangat kompleks antara satu dengan lainnya dalam kelompok lulusan yang sama. Penilaian sederhana yaitu bila lulusan dapat diterima bekerja sesuai dengan bidang keilmuannya dan bila diterima di perguruan tinggi terkemuka bagi yang melanjutkan studi, maka lembaga pendidikan tersebut dinilai bermutu.

Pendidik yang profesional, kepemimpinan pendidikan yang kompeten, dan amanah, kurikulum yang relevan, sarana dan prasarana yang lengkap merupakan beberapa faktor yang berpengaruh pada mutu pendidikan. 
Ditambah lagi siswa itu sendiri harus memiliki kemauan dan kemampuan untuk mencapai mutu.

Konsep mutu dipandang sebagai konsep yang relatif, tidakmutlak. Bermutu menurut satu perspektif belum tentu bermutu menurut perspektif lain. Pandangan ini benar, tetapi perlu ada yang ditegaskan bahwa ada mutu yang pasti dengan ukuran yang pasti, itulah perlunya standar baku. Suatu produk atau jasa dapat dinilai mutunya apabila barang atau jasa tersebut telah sesuai dengan spesifikasi yang ditetapkan sebelumnya.

Dalam bidang pendidikan, mutu lulusan baru dapat dinilai mutunya apabila mereka telah memiliki kemampuan sesuai dengan perencanaan dalam kurikulum yang ditetapkan. Salah satu pendapat yang mengatakan bahwa pihak eksternal memiliki otoritatif dalam penjaminan mutu, sedangkan pendapat lain mengatakan sebaliknya bahwa pihak internal yang memiliki kebutuhan terhadap mutu pendidikan. Pemahaman ini mendorong pada pentingnya teori manajemen yang substantif mencapai standar mutu dan memberikan kepuasan kepada stakeholders secara nyata. Konsep mutu dalam bidang pendidikan di sini adalah kesesuaian sistem pendidikan dengan standar yang ditetapkan serta memenuhi harapan dan kepuasan stakeholders layanan jasa pendidikan.

\section{Tantangan Profesi Pendidik pada Era Globalisasi}

Dalam rangka meningkatkan profesionalisme pendidik, terjadinya revolusi teknologi informasi merupakan sebuah tantangan yang harus dicarikan solusinya. Adanya perkembangan teknologi informasi yang demikian cepat akan mengubah pola hubungan guru dengan murid, teknologi pembelajaran dan sistem pendidikan secara keseluruhan. Pendidik dituntut untuk menyesuaikan hal tersebut. Adanya revolusi informasi seharusnya dimanfaatkan dengan baik untuk meningkatkan kualitas pembelajaran, bukan sebaliknya menjadi penghambat. Untuk itu, perlu didukung oleh suatu kehendak dan etika yang dilandasi oleh ilmu pendidikan dengan dukungan berbagai pengalaman para praktisi pendidikan di lapangan.

Perkembangan teknologi, terutama teknologi informasi menyebabkan peranan lembaga pendidikan mulai tergeser. Lembaga pendidikan tidak lagi 
menjadi satu-satunya pusat pembelajaran karena aktivitas belajar tidak lagi terbatas oleh ruang dan waktu. Peran pendidik juga tidakakan menjadi satusatunya sumber belajar karena banyak sumber belajar dan sumber informasi yang mampu memfasilitasi seseorang untuk belajar.

Namun, bagaimanapun kemajuan teknologi informasi di masa yang akan datang, keberadaan lembaga pendidikan tetap akan diperlukan oleh masyarakat. Kita tidak dapat menghapus keberadaan lembaga pendidikan hanya karena telah ada teknologi informasi yang semakin maju. Ada sisi-sisi tertentu dari fungsi dan peranan lembaga pendidikan yang tidak dapat tergantikan, misalnya hubungan pendidik dan anak didik dalam fungsi mengembangkan kepribadian atau membina hubungan sosial, rasa kebersamaan, kohesi sosial, dan lain-lain. Teknologi informasi hanya mungkin menjadi pengganti fungsi penyebaran informasi dan sumber belajar. Bahan ajar yang semula disampaikan oleh pendidik di depan kelas, dapat diubah menjadi pembelajaran yang diindividualisasikan melalui jaringan internet yang dapat diakses oleh siapapun dan dari manapun.

Sejumlah kecenderungan dan tantangan globalisasi yang harus diantisipasi pendidik dengan pentingnya mengedepankan profesionalisme yaitu antara lain; 1) Perkembangan ilmu pengetahuan dan teknologi yang begitu cepat dan mendasar. Dengan kondisi ini, seorang pendidik diharapkan dapat menyesuaikan diri dengan responsif, arif, dan bijaksana. Responsif artinya pendidik harus bisa menguasai dengan baik produk IPTEK, terutama yang berkaitan dengan dunia pendidikan, seperti pembelajaran dengan multimedia, 2) Krisis "moral" yang melanda bangsa dan negara ini akibat pengaruh IPTEK dan globalisasi telah terjadi pergeseran nilai-nilai yang ada dalam kehidupan masyarakat. Nilai-nilai yang sangat menjunjung tinggi moralitas bisa saja dapat bergeser seiring dengan pengaruh IPTEK dan globalisasi. Di kalangan remaja sangat begitu terasa akan pengaruh IPTEK dan globalisasi. Pengaruh hiburan baik yang berasal dari media cetak maupun elektronik yang menjurus pada hal-hal pornografi telah menjadikan sebagian remaja tergoda dalam suatu "pilihan" kehidupan yang menjurus pada pergaulan bebas dan materialisme, 3) Krisis "sosial", seperti kriminalitas, kekerasan, pengangguran, dan kemiskinan yang terjadi dalam masyarakat. Akibat perkembangan industri dan kapitalisme maka muncul 
masalah-masalah sosial dalam masyarakat. Mereka yang lemah secara pendidikan, akses, dan ekonomi akan menjadi korban ganasnya industrialisasi dan kapitalisme. Ini merupakan tantangan bagi guru dalam merespon realitas ini, terutama dalam kaitannya dengan dunia pendidikan. Sekolah sebagai lembaga formal yang sudah mendapat kepercayaan dari masyarakat harus mampu menghasilkan peserta didik yang siap hidup dalam situasi dan kondisi bagaimanapun. Dunia pendidikan harus menjadi solusi dari suatu masalah sosial bukan menjadi bagian, bahkan menjadi penyebab dari masalah sosial tersebut, 4) Krisis identitas sebagai bangsa. Dalam dekade terakhir, ada kecenderungan menipisnya jiwa nasionalisme di kalangan generasi muda. Hal ini dapat dilihat dari beberapa indikator, seperti kurang apresiasinya generasi muda terhadap kebudayaan asli Indonesia dan pola dan gaya generasi muda yang kebarat-baratan. Melihat realitas perilaku generasi muda ini, pendidik sebagai penjaga nilai-nilai termasuk nilai nasionalisme harus mampu memberikan kesadaran kepada generasi muda akan pentingnya jiwa nasionalisme dalam kehidupan berbangsa dan bernegara. Tidak semua nilai-nilai global harus diterima dan tidak semua nilai-nilai "tradisional" bangsa harus ditinggalkan. Nilai-nilai bangsa yang mengedepankan musyawarah, gotong-royong, kerja sama, dan saling membantu tetap relevan dalam menyelamatkan generasi mendatang di tengah kehidupan pada era globalisasi yang membawa nilai-nilai sebaliknya, dan 5) Adanya perdagangan bebas, baik tingkat ASEAN, Asia Pasifik, maupun dunia. Kondisi ini membutuhkan kesiapan yang matang terutama dari segi SDM. Indonesia membutuhkan SDM yang handal untuk bersaing dengan bangsa-bangsa lain. Dunia pendidikan mempunyai peranan yang penting dan strategis dalam menciptakan SDM yang berkualitas. Oleh karena itu, dibutuhkan pendidik yang visioner, kompeten, berdedikasi tinggi dan berkomitmen agar mampu membekali peserta didik dengan sejumlah kompetensi yang diperlukan dalam kehidupan di tengah masyarakat yang sedang dan terus berubah.

Permasalahan di atas merupakan tantangan profesi pendidik pada era globalisasi. Apakah peranannya akan digantikan oleh teknologi informasi atau pendidik yang memanfaatkan teknologi informasi untuk menunjang profesinya. Oleh karena itu, dunia pendidikan harus menyiapkan seluruh 
unsur dalam sistem pendidikan agar tidak tertinggal atau ditinggalkan teknologi informasi tersebut. Melalui penerapan dan pemilihan teknologi informasi yang tepat, maka perbaikan mutu yang berkelanjutan dapat diharapkan. Perbaikan yang dilakukan secara konsisten akan mendorong orientasi pada perubahan untuk memperbaiki dunia pendidikan, khususnya bagi pendidik. Adanya revolusi teknologi informasi dapat menjadi tantangan bagi pendidik. Hal ini akan menjadi peluang baik bila pendidik mampu menyikapinya dengan terbuka dan berusaha memilih jenis teknologi informasi yang tepat, sebagai penunjang proses pembelajaran.

\section{Strategi Meningkatkan Profesionalisme Pendidik}

Upaya peningkatan profesionalisme pendidik selalu dan terus dilakukan oleh pemerintah dengan berbagai cara dan ragamnya, mulai dari cara yang sifatnya lokal oleh sekolah yang bersangkutan, Dinas Pendidikan setempat dan dilakukan pula oleh Pemerintah Pusat, dalam hal ini Kementerian Pendidikan dan Kebudayaan.

Sumber daya manusia yang berkualitas yang didapatkan dari program pengembangan menjadi komoditi kebijakan pemerintah, tentunya harus direncanakan dengan baik dengan melakukan analisis posisi bersamaan dengan mencermati kekuatan, kelemahan, peluang, dan tantangan. Salah satu hal penting yang mesti dijadikan pertimbangan ketika program pengembangan pendidik yaitu asas equity dan equality. Kedua asas tersebut memberikan kesempatan yang sama kepada semua pendidik dengan tidak membedakan antara pegawai tetap atau honorer.

Salah satu upaya yang dilakukan pemerintah untuk meningkatkan profesionalisme pendidik adalah melakukan sertifikasi. Landasan utama yang menjadi acuan program sertifikasi dan kompetensi pendidik adalah Undang-Undang RI No. 20 Tahun 2003 tentang Sistem Pendidikan Nasional, pada Pasal 42 Ayat 1 menyatakan bahwa, "Pendidik harus memiliki kualifikasi minimum dan sertifikat sesuai dengan jenjang kewenangan mengajar, sehat jasmani dan rohani, serta memiliki kemampuan untuk mewujudkan tujuan pendidikan nasional.

Selanjutnya pada tataran aplikatifnya diatur dalam Undang-undang RI No. 14 Tahun 2005 tentang Guru dan Dosen, pada Pasal 8 menyatakan, 
"Guru wajib memiliki kualifikasi akademik, kompetensi, sertifikat pendidik, sehat jasmani dan rohani, serta memiliki kemampuan untuk mewujudkan tujuan pendidikan nasional." Pada Pasal 9 menyatakan, "Kompetensi guru sebagaimana dimaksud pada Pasal 8 meliputi kompetensi pedagogik, kompetensi kepribadian, kompetensi sosial, dan kompetensi profesional yang diperoleh melalui pendidikan profesi." Selanjutnya pada pasal 11 ayat 1 menyatakan, "Sertifikat pendidik sebagaimana dalam Pasal 8 diberikan kepada guru yang telah memenuhi persyaratan."

Hal ini juga disebutkan pada Peraturan Pemerintah Nomor 19 Tahun 2005 tentang Standar Nasional Pendidikan pada Pasal 28 Ayat 1 disebutkan, "Pendidik harus memiliki kualifikasi akademik dan kompetensi sebagai agen pembelajaran, sehat jasmani dan rohani, serta memiliki kemampuan untuk mewujudkan tujuan pendidikan nasional."

\section{Pengembangan Sistem Penjaminan Mutu Pendidik}

Harkat dan martabat suatu profesi ditentukan oleh kualitas layanan profesi yang didukung oleh praktisi profesi yang dijamin mutunya. Oleh karena itu, perlu ditetapkan standar kompetensi pendidik yang menjadi acuan penilaian kompetensi. Lulusan dari lembaga terakreditasi penyelenggara pendidikan profesi pendidik yang lulus uji kompetensi akan mendapat Sertifikat Kompetensi dan Nomor Registrasi sekaligus merupakan pengakuan resmi atas kemampuannya dan bukti kewenangannya untuk mengajar sesuai dengan jenjang dan jenis pendidikan dan/atau bidang studi tertentu. Untuk menjamin pengembangan kemampuan guru sesuai dengan tuntutan perkembangan, sertifikat kompetensi ini perlu diperbaharui oleh guru lima tahun sekali. Sehubungan dengan hal ini perlu dikembangkan sistem penjaminan mutu guru dengan membentuk badan pelaksana uji kompetensi dalam rangka sertifikasi yang secara bertahap akan dikembangkan menjadi lembaga independen semacam Badan Sertifikasi Nasional untuk Profesi Guru.

\section{Pembenahan Manajemen Guru}

Proses rekrutmen, pengangkatan, dan penempatan guru selama ini diwarnai oleh KKN. Akibatnya, calon yang terseleksi dan diangkat sebagai 
guru banyak yang kurang berkualitas, dan penempatan guru kurang tepat dan merata. Guru sebagai profesi harus bercirikan pada transparansi, akuntabilitas, dan profesionalisme. Oleh karena itu, untuk ke depannya, seleksi dan penempatan guru harus benar-benar transparan, akuntabel, dan profesional. Selain itu, perlu dibuat perangkat perundang-undangan untuk menjamin sistem pembinaan karir guru sebagai profesi. Perangkat perundang-undangan tersebut harus memberi kepastian kepada guru dalam jaminan perlindungan profesi, penghargaan yang sepadan dengan profesi dan produktivitas, serta kesempatan untuk berkembang, baik melalui studi lanjut, penugasan ke satuan pendidikan atau instansi pendidikan yang dapat memberi peluang pengembangan profesi. Dengan jaminan pembinaan dan pengembangan karir yang jelas serta dibarengi dengan tingkat renumerasi yang memadai, profesi guru akan lebih menarik bagi masyarakat.

\section{Pembenahan Sistem Renumerasi Guru}

Dengan alasan keterbatasan kemampuan keuangan pemerintah, selama ini gaji yang ditetapkan untuk guru jauh dari layak. Hal ini diperburuk oleh langkanya peluang bagi guru untuk mengembangkan profesionalisme melalui penataran, studi lanjut, dan penugasan lainnya yang berorientasi pada pengembangan karir. Keadaan ini diperburuk lagi dengan sistem penggajian yang menyamakan gaji guru dengan pangkat/golongan dan masa kerja tanpa memperhatikan kinerja yang dicapai oleh guru. Menyadari sistem renumerasi yang kurang menantang dan kurang memperhatikan kinerja tersebut, perlu dilakukan pembenahan terhadap sistem renumerasi guru.

Pembenahan sistem renumerasi guru menyangkut beberapa hal pokok. Pertama, gaji guru harus disesuaikan/ditingkatkan sampai jumlah yang layak bagi kehidupan yang sejahtera. Kedua, selain pangkat/golongan, besarnya renumerasi seorang guru harus ditentukan oleh kinerja guru yang bersangkutan. Guru yang berprestasi (misalnya ditunjukkan oleh prestasi siswanya) harus memperoleh imbalan yang lebih tinggi. Ketiga, pembinaan karir harus merata bagi semua guru. Akan tetapi, peluang jabatan dan pembinaan karir/profesionalisme harus diutamakan bagi guru yang berprestasi. Pembenahan ini memerlukan komitmen yang tinggi dari pemerintah dan partisipasi masyarakat yang luas. 


\section{Pengembangan Pola Pendidikan Profesi Guru}

Undang-undang No. 20 Tahun 2003 tentang Sistem Pendidikan Nasional, menyebutkan bahwa salah satu konsekuensi dari pengakuan guru sebagai profesi adalah diperlukannya pendidikan profesi yang berbasis pendidikan tinggi. Hal ini sesuai dengan persyaratan kualifikasi guru sebagaimana diatur dalam Standar Nasional Pendidikan. Selain itu, perlu pula dikembangkan pola pendidikan yang benar-benar berorientasi pada pengembangan kemampuan profesional. Pola-pola yang dapat dilakukan antara lain pola terpadu, yaitu pendidikan profesi guru yang memberikan bekal keilmuan dalam bidang studi dan kemampuan profesi pada waktu bersamaan. Pada akhir masa studinya, calon guru memperoleh gelar kesarjanaan pada bidang studinya dan lisensi/sertifikat guru. Alternatif lainnya adalah pola pendidikan berkelanjutan yaitu selama periode tertentu (misalnya 4 tahun). Pendidikan difokuskan pada ilmu tertentu yang diakhiri dengan diperolehnya gelar kesarjanaan, dan dilanjutkan dengan program profesi selama satu tahun untuk memperoleh lisensi menjalankan praktik sebagai guru.

Untuk menunjang tercapainya pendidikan profesi guru yang baik, perlu dijalin kemitraan yang intensif antara perguruan tinggi penyelenggara pendidikan profesi guru dan sekolah. Kemitraan ini harus menguntungkan kedua belah pihak. Misalnya perguruan tinggi dapat mengembangkan kemampuan profesional mahasiswanya di sekolah, sedangkan guru dapat mengikuti perkembangan dunia pendidikan. Untuk menarik minat calon mahasiswa yang berkemampuan tinggi untuk memasuki program pendidikan profesi guru, perlu dikembangkan bentuk-bentuk insentif bagi mahasiswa pendidikan profesi guru, misalnya ikatan dinas, sistem sandwich dalam program induksi, dan penawaran beasiswa lainnya, baik dari pemerintah pusat, pemerintah daerah, maupun dunia usaha/industri.

Untuk menjamin mutu pendidikan, perguruan tinggi yang boleh menyelenggarakan pendidikan profesi guru hanyalah perguruan tinggi yang terakreditasi oleh Badan Akreditasi Nasional Pendidikan Guru, baik sebagai lembaga akreditasi tersendiri maupun bagian dari BAN PT yang sudah ada. 


\section{Pengembangan Organisasi Profesi Guru}

Keberadaan organisasi profesi diyakini penting bagi setiap jenis profesi karena organisasi tersebut mengoordinasikan dan mengawasi jalannya suatu praktik profesi, sebagaimana diatur dalam kode etik profesi yang dimiliki dan dihayati oleh setiap profesi. Organisasi tersebut juga menangani berbagai kegiatan, seperti urusan lisensi, dewan kehormatan profesi, pemantauan pelaksanaan kode etik profesi, dan pengembangan pendidikan dan pelatihan profesi. Karena di Indonesia belum ada organisasi profesi yang benar-benar mencurahkan perhatiannya secara terfokus pada profesi guru. Organisasi ini dapat dikembangkan dari PGRI, ISPI, dan Organisasi Guru Bidang Studi.

\section{Penyusunan Kode Etik Guru sebagai Profesi}

Selain Undang-undang Guru dan Dosen yang sudah terwujud, penyusunan kode etik guru sebagai profesi juga sangat diperlukan. Sebagaimana profesi-profesi lainnya seperti dokter dan advokat, guru sebagai profesi memerlukan kode etik dalam menjalankan profesinya. Kode etik yang dimaksud adalah seperangkat kaidah perilaku sebagai pedoman yang harus dipatuhi dalam mengemban suatu profesi. Kode etik ini merupakan persetujuan bersama yang timbul dari para anggota sesuai dengan nilai-nilai ideal yang mereka harapkan.

Dalam menjalankan tugasnya, guru harus selalu terikat pada kode etik tersebut. Guru dengan sendirinya akan menghindarkan dirinya dari melakukan tindakan-tindakan yang tidak terpuji atau merugikan peserta didik. Dengan demikian, kualitas layanan pendidikan akan maksimal, kinerja guru optimal, dan mutu lulusan akan sangat baik. Selanjutnya masa depan masyarakat, bangsa, dan negara Indonesia dapat ditumpukan pada kinerja dan profesionalisme guru. Hanya guru profesional dan sungguh-sungguh yang secara penuh dapat melaksanakan pembangunan di segala bidang. Misalnya ekonomi, politik, hukum, dan kesehatan secara efektif dan efisien. Untuk itu, sudah saatnya masyarakat dan pemerintah menempatkan dan menghargai jabatan/pekerjaan guru sebagai profesi yang sama atau lebih baik dari profesi lainnya. 
Langkah-langkah di atas memberikan makna bahwa jaminan mutu pengembangan profesionalisme pendidik harus dilihat dari kebutuhan tugas, baik berkaitan dengan siswa, manajemen kelas, maupun penyelenggaraan pendidikan. Jaminan mutu harus dipandang sebagai kegiatan yang bervariasi untuk mewujudkan efisiensi, produktivitas dan memberikan keyakinan kepada masyarakat.

Implementasi pengembangan SDM parameter keberhasilannya dikaitkan dengan faktor investasi. Gary S. Becker melihat pengembangan individu melalui model pendidikan dalam jabatan merupakan investasi penting dalam human capital. (Gary S.Becker, 1993: 30). Investasi yang ditanamkan dalam model pendidikan on the job menjawab tuntutan jangka panjang. Pendidikan dan pelatihan memberikan solusi untuk mengatasi masalah pekerjaan dari persoalan sederhana sampai pada masalah yang paling sulit sehingga dapat diatasi melalui peningkatan keterampilan dan pengetahuan. Model pendidikan on the job adalah model yang paling efisien terutama jika dikaitkan dengan tingkat pengalaman yang bersangkutan. Jika diterapkan secara adil dan merata sebagai model prioritas dalam pengembangan profesionalisme pendidik, maka semua pendidik akan memiliki tingkat kompetensi yang dapat melaksanakan pekerjaan secara baik.

Dalam platform pengembangan profesionalisme pendidik, Malik Fajar menyusun kerangka strategi dalam memberikan jaminan mutu dan juga berkaitan dengan reformasi pendidikan, meliputi: Pertama, melaksanakan otonomi dan desentralisasi. Manajemen pengembangan profesionalisme pendidik dilaksanakan oleh daerah,yakni pemerintah kabupaten/kota sebagai subjek pengembangan. Kedua, melaksanakan manajemen berbasis sekolah. Pengembangan profesionalisme pendidik berorientasi untuk meningkatkan pengetahuan, sikap, dan keterampilan untuk memenuhi tuntutan otonomi dan pemberdayaan sekolah. Sikap profesional pendidik diharapkan memberikan arti penting dalampeningkatan efisiensi, mutu, dan pemerataan pendidikan. Ketiga, melakukan review kurikulum. Pengembangan profesionalisme pendidik memberikan peluang terhadap peningkatan mutu kurikulum berbasis lingkungan/lokal yang dibekali kompetensi tertentu sehingga mampu menjawab kebutuhan masyarakat setempat. Keempat, 
menerapkan sistem manajemen mutu. Pengembangan profesionalisme pendidik diharapkan memberikan kemampuan manajerial untuk menata kembali manajemen organisasi dengan memberikan peran yang luas kepada masyarakat. Kelima, penerapan student center learning. Melalui pengembangan profesionalisme pendidik diharapkan memberikan solusi terhadap persoalan masa depan berkaitan dengan kreativitas dan penciptaan proses pembelajaran yang berpusat pada siswa. (A. Malik Fajar, 1999: 57-61)

Platform di atas memberikan makna bahwa jaminan mutu pengembangan profesionalisme pendidik harus dilihat dari kebutuhan tugas, baik berkaitan dengan peserta didik, manajemen kelas, maupun penyelenggaraan pendidikan. Jaminan mutu harus dipandang sebagai kegiatan yang bervariasi untuk mewujudkan efisiensi, produktivitas, dan memberikan keyakinan kepada masyarakat.

\section{SIMPULAN}

Dalam rangka mencapai mutu yang tinggi dalam bidang pendidikan, peranan pendidik sangatlah penting, bahkan sangat utama. Untuk itu, profesionalisme pendidik harus ditegakkan dengan cara pemenuhan syaratsyarat kompetensi yang harus dikuasai oleh setiap pendidik, baik di bidang penguasaan keahlian materi keilmuan maupun metodologi.

Untuk mencapai kondisi pendidik yang profesional, para pendidik harus menjadikan orientasi mutu dan profesionalisme pendidik sebagai etos kerja mereka dan menjadikannya sebagai landasan orientasi berperilaku dalam tugas-tugas profesinya. Karenanya kode etik profesi pendidik harus dijunjung tinggi.

Dari pembahasan sebelumnya tampak bahwa untuk menjadi pendidik profesional tidaklah mudah. Seorang pendidik yang ingin menjadi pendidik yang profesional perlu senantiasa beradaptasi dan merespon tantangan paradigma baru profesi pendidik. Seorang pendidik hendaknya memiliki motivasi kuat untuk menjadi maju dan profesional. Semua pendidik bisa menjadi profesional asalkan ada niat, keinginan, motivasi, dan komitmen untuk melakukan dan menggapainya. 


\section{DAFTAR PUSTAKA}

Becker, Gary S., Human Capital: A Theoritical and Empirical Analysis With Special Reference to Education, Chicago: Chicago Press, Third Edition, 1993.

Crosby, Philip., Quality is Free: The Art of Making Quality Certain, New York: Mc Graw Hill, 1987.

Danim, Sudarwan, dan Rahayu, Wiwien W., Profesi dan Profesionalisasi, Yogyakarta: Paradigma Indonesia, 2009.

Deming, W. Edward, Out of The Crisis, Cambridge: Cambridge University Press, 1986.

Fajar, A. Malik, Platform Reformasi Pendidikan dan Pembangunan Sumber Daya Manusia, Jakarta: Depag RI, 1999.

Feigenbaum, A.V., Total Quality Control, New York: Mc Graw Hill, 1988.

Hoyle, Eric, The Process of Management, in E523 Management an School, Milton Keynes, Open University Press, 1981.

Juran, J.M., Juran on Leadership for Quality, New York: Macmillan, 1989.

Mulyasa, Enco, Standar Kompetensi dan Sertifikasi Guru, Bandung:ROSDA, 2007.

Peraturan Pemerintah RI Nomor 19 tahun 2005 tentang Standar Nasional Pendidikan.

Soedijarto, Pendidikan Nasional sebagai Proses Transformasi Budaya, Jakarta: Balai Pustaka, 2003.

Sutisna, Oteng, Administrasi Pendidikan: Dasar Teoritis untuk Praktik Profesional, Bandung: Angkasa, 1991.

Undang-Undang No. 20 tahun 2003 tentang Sistem Pendidikan Nasional.

Undang-Undang No. 14 tahun 2005 tentang Guru dan Dosen. 